\title{
TOTAL NITORGEN CONTENT FROM EARTHWORM (EISENIA FOETIDA) USING THE KJELDAHL METHOD
}

\author{
Zarina Zakaria, Alina Rahayu Mohamed, NoOr Hasyierah Mohd Salleh \\ AND Siti NurSheEla Abu MaNSOR \\ School of Bioprocess Engineering, University Malaysia Perlis, 02600 Arau, Perlis.
}

zarinaz@unimap.edu.my

\begin{abstract}
In the fish aquaculture management, fish feed is identified as a major problem. The high cost and scarcity of fishmeal in formulated feeds have led to the use of other protein sources such as earthworms and animal by-product. Earthworm is an alternative source of protein to replace the fish meal in the fish feed formulation. In this study, total nitrogen content in the earthworm powder is determined using the Kjeldahl method by employing the statistical software, Full Factorial Design (FFD) which could provide the significant information about the studied parameters. The parameters are, the digestion time ( $\mathrm{min})$ and the volume of sulfuric acid (H2SO4) (ml). From the analysis of variance (ANOVA), the volume of $\mathrm{H} 2 \mathrm{SO} 4$ and the interaction between digestion time and the volume of $\mathrm{H} 2 \mathrm{SO} 4$ are found to be important parameters in the nitrogen determination process via the Kjeldahl method. The highest nitrogen content obtained was $12.23 \%$, when using $15 \mathrm{ml} \mathrm{H} 2 \mathrm{SO} 4$ and 60 mins of digestion time. The value of R2 is 0.9986 , which shows that the selected parameters (the digestion time and the volume of $\mathrm{H} 2 \mathrm{SO} 4$ ) and its corresponding levels are highly correlated to the percentage nitrogen content in earthworm powder using the Kjeldahl method.
\end{abstract}

ABSTRAK: Dalam pengurusan akuakultur ikan, makanan telah dikenalpasti sebagai masalah utama. Kos yang tinggi serta kekurangan sumber makanan telah menggalakkan pencarian sumber protein baru seperti cacing tanah dan hasil sampingan sembelihan haiwan ternakan. Cacing adalah sumber protein alternatif menggantikan ramuan ikan (fish meal) dalam formulasi makanan ikan. Dalam kajian ini, kandungan jumlah nitrogen dalam serbuk cacing tanah telah dianalisa menggunakan kaedah Kjeldahl dengan menggunapakai perisian statistikal iaitu Full Factorial Design (FFD) yang boleh memberikan maklumat yang penting berkenaan dengan parameter-parameter yang dikaji. Parameter-parameter tersebut adalah masa pencernaan ( $\mathrm{min}$ ) dan isipadu asid sulfurik $\left(\mathrm{H}_{2} \mathrm{SO}_{4}\right)(\mathrm{ml})$. Daripada analisa varian (ANOVA), isipadu $\mathrm{H}_{2} \mathrm{SO}_{4}$ dan interaksi antara masa pencernaan dan isipadu $\mathrm{H}_{2} \mathrm{SO}_{4}$ telah dikenalpasti sebagai parameter-parameter utama dalam proses penentuan kandungan nitrogen melalui kaedah Kjeldahl. Kandungan nitrogen yang tertinggi diperolehi adalah $12.23 \%$ bila menggunakan $15 \mathrm{ml} \mathrm{H}_{2} \mathrm{SO}_{4}$ dan 60 minit masa pencernaan. Nilai $\mathrm{R}^{2}$ adalah 0.9986 menunjukkan bahawa parameterparameter (masa pencernaan dan isipadu $\mathrm{H}_{2} \mathrm{SO}_{4}$ ) dan aras yang dipilih mempunyai perkaitan langsung yang tinggi dengan kandungan nitrogen dalam serbuk cacing dengan menggunakan kaedah Kjeldahl.

KEYWORDS: nitrogen content; earthworm; Kjeldahl method

\section{INTRODUCTION}

The aquaculture sub-sector in Malaysia is divided into marine aquaculture and freshwater aquaculture. For freshwater aquaculture, pond culture is the main system 
employed [1].Aquaculture is a prominent approach to increase the fish production to suffice fish available to the populace. It was reported that 1.43 million tonnes of fish catches last year, not including squids, prawns and oysters, are not enough to feed a population of 28.5 million [2].

Under the Third National Agriculture Policy, aquaculture production in Malaysia is targeted to reach 600,000 tonnes annually by the year 2010 , which include 200,000 tonnes freshwater fish. This multifold increase in production from its current level will place an increasing demand on the supplies of feed (formulated feed and trash feed), since the aquaculture sector is targeted at high value species such as grouper, snapper and penaeid prawn. These species require high inputs of fish protein in their feed [1]. The issue of fish feed is identified as major problem in the fish aquaculture management.

The high cost and scarcity of fishmeal in formulated feeds has led to the use of other protein sources such as earthworms, insects, snail, mussels, maggot, frog, and plants in fish feeds [3].However, there are some problems related to the quality of protein sources for fish feed. The occurrence of leaching of total protein content and lipid which was low $(<15 \%)$ in all fish silage pellets such as silage-poultry by-product meal was reported [4]. Some small scale keli (Clarias spp) or catfish breeders in Malaysia prefer to use the animal by-product such as chicken gut as the fish meal to the catfish due to its low in price and easily available. However, this leads to the odour pollution around the fish pond and its nearby area. Moreover, the tissue strength of fish meat was found to be low that it is only suitable for local use only.

Eisenia feotida or earthworm is viewed as possible alternative of protein source in fish meal. Moreover, earthworms are being used as fish bait and this practice is common in fishing activity throughout Malaysia. Owing to their high reproductive rate, low feeding costs and ease of breeding in captivity, earthworms constitute an extremely interesting protein source for fish feed. Mostly, earthworms with high protein are also used to feed chickens, pigs and as a dietary supplement for ornamental fish [5, 6]. The earthworm in dried or dehydrated form has protein content higher than other protein source such as fish meal, meat and bone meal, and soybean meal [7].Moreover, Eisenia feotida proteins were not toxic to a human cell line at low concentrations [8].

Determination of protein content is an important measurement especially in biochemical analysis such as electrophoresis, immuno-analysis, molecular biology as well as other research applications [9]. The protein concentration can be determined by using different methods such as Kjeldahl method, combustion method, Bradford method, Biuret method, Lowry method, UV-visible spectroscopic method [9-13]. The Kjeldahl method provides several advantages: it could work under appropriate conditions with analysis simultaneously. Moreover, the distillation process is very fast and efficient [11]. On the other hand, Biuret method is impractical because of the detection limit and large volumes of sample requirement [9].To the authors best knowledge, there has yet any papers published on the use of statistical tools (Design Expert software) in the determination of protein content in earthworm powder by employing the Kjeldahl method of analysis. Utilization of statistical tools like Design Expert software offers many advantages.

Design of experiment (DOE) is an efficient tool in such a way that it could eliminate the time consuming phase which could not be achieved when using the conventional OFAT (one-factor-at-a-time) method [14]. Furthermore, the OFAT method is inefficient, requires more experimentation than a factorial and unable to detect interactions between the parameters or factors [15]. Factorial experiments through $2^{\mathrm{k}}$ study are the only way to discover interactions between parameters [15]. A $2^{\mathrm{k}}$ design is useful prior to response 
surface study in order to conduct screening experiments to identify the important parameters that had effects on the process [16].

Therefore, in consideration of this, the objectives of this paper are to screen the active parameters which are $\mathrm{H}_{2} \mathrm{SO}_{4}$ volume $(15-25 \mathrm{ml})$ and digestion time (40-60 min) that play significant roles in protein content determination in earthworm powder. These parameters were chosen since for standard operating procedure of Kjeldahl, the minimum conditions are $25 \mathrm{ml}$ and $60 \mathrm{~min}$ for $\mathrm{H}_{2} \mathrm{SO}_{4}$ volume and digestion time respectively. Full Factorial Design (FFD) was used to achieve the objective and consequently, the process conditions that would give the highest protein content in earthworm powder using the Kjeldahl protein analysis could be obtained.

\section{MATERIALS AND METHODS}

\subsection{Materials}

Earthworm powder was purchased from local company. Sodium hydroxide, $\mathrm{H}_{2} \mathrm{SO}_{4}$, boric acid and the Kjeldahl tablets were purchased from Merck.

\subsection{Preparation for Scrubber}

Five liters of sodium hydroxide $(8 \%)$ was prepared. The $\mathrm{pH}$ indicator $(0.5 \mathrm{~g}$ bromothymol blue was dissolved in $500 \mathrm{ml}$ ethanol (95\%) and $500 \mathrm{ml}$ distilled water was added to the solution) was made and added into the $8 \%$ of $\mathrm{NaOH}$. Activated charcoal in granular form was installed at the scrubber unit (Buchi Scrubber B-414, Switzerland).

\subsection{Preparation for Digestion}

One gram of the earthworm powder was weighed on a nitrogen free paper before it was placed in a digestion tube. Two Kjeldahl tablets $(10 \mathrm{~g})$ were added to increase the speed of reaction in digestion process. $\mathrm{H}_{2} \mathrm{SO}_{4}(98 \%)$ with varying volume was added and the sample was suspended by gently swirling the tube. Additional blanks (without earthworm) were prepared. The digest system K-437 (Buchi, Switzerland) unit was preheated at $300{ }^{\circ} \mathrm{C}$ for $30 \mathrm{~min}$. The digestion process was started from $300{ }^{\circ} \mathrm{C}$ up to $420^{\circ} \mathrm{C}$ with varying digestion time. After the sample was completely digested, it was cooled down to ambient temperature prior for distillation.

\subsection{Preparation for Distillation}

One liter of boric acid (4\%) with $\mathrm{pH} 4.65,1$ liter $\mathrm{H}_{2} \mathrm{SO}_{4}(0.25 \mathrm{M})$ and $500 \mathrm{ml} \mathrm{NaOH}$ (10\%) were prepared. The cold sample was distilled using Auto Kjeldahl Unit K-370 (Buchi, Switzerland).

\subsection{Preparation for Titration}

Once the distillation process was done, the distilled sample was titrated with $0.25 \mathrm{M}$ sulfuric acid from KjelFlex (Buchi, Switzerland) and stop once the colour became slight purple or $\mathrm{pH}$ 4.65. The volume of titrant used was recorded.

\subsection{Calculation of \% Nitrogen:}

$$
\text { For } 0.25 \mathrm{M} \mathrm{H}_{2} \mathrm{SO}_{4} \text { : }
$$

$$
\% N=\frac{\left(V_{\text {sample }}-V_{\text {blank }}\right) \mathrm{ml} \times 0.05 \times 14.00}{\text { Weight of sample }(g)}
$$




\subsection{Calculation of \% Protein:}

$\%$ Protein $=\%$ Nitrogen $\mathrm{x}$ empirical protein factor.

A conversion factor $(F)$ is used to convert the measured nitrogen concentration to a protein concentration. A conversion factor of 6.25 (equivalent to $0.16 \mathrm{~g}$ nitrogen per gram of protein) is used for many applications, however, this is only an average value, and each protein has a different conversion factor depending on its amino-acid composition [17].

\section{RESULTS AND DISCUSSION}

A 2 level-two-factor-design $2^{2}$ with digestion time, A (40-60 min) and volume of $\mathrm{H}_{2} \mathrm{SO}_{4}, \mathrm{~B}(15-25 \mathrm{ml})$ was employed (Table 1). These 2 factors are used to view its correlation with the response (R1) which is the percentage of nitrogen content (\% Nitrogen). $2^{2}$ With 7 centre points corresponds to 17 experimental runs were suggested. The results are obtained and tabulated in Table 2 .

Table 1: Parameters under investigation.

\begin{tabular}{lccccc}
\hline & & & \multicolumn{3}{c}{ Range and levels } \\
\hline Independent variables & Units & Symbols & -1 & 0 & +1 \\
Digestion time & mins & A & 40 & 50 & 60 \\
Volume of $\mathrm{H}_{2} \mathrm{SO}_{4}$ & $\mathrm{ml}$ & B & 15 & 20 & 25 \\
\hline
\end{tabular}

Table 2: Experimental results for earthworm protein.

\begin{tabular}{lcccc}
\hline Std & Run & $\begin{array}{c}\text { Factor 1 } \\
\text { A:time digestion } \\
\text { (minute) }\end{array}$ & $\begin{array}{c}\text { Factor } \mathbf{2} \\
\text { B:sulfuric acid } \\
\text { (ml) }\end{array}$ & $\begin{array}{c}\text { Response 1 } \\
\text { RI (\% } \\
\text { Nitrogen) }\end{array}$ \\
\hline $\mathbf{1 3}$ & 1 & 50.00 & 20.00 & 12.21 \\
$\mathbf{1 2}$ & 2 & 60.00 & 25.00 & 0.49 \\
$\mathbf{1 1}$ & 3 & 60.00 & 25.00 & 1.12 \\
$\mathbf{1}$ & 4 & 40.00 & 15.00 & 11.41 \\
$\mathbf{1 7}$ & 5 & 50.00 & 20.00 & 11.98 \\
$\mathbf{3}$ & 6 & 40.00 & 15.00 & 11.82 \\
$\mathbf{8}$ & 7 & 40.00 & 25.00 & 1.17 \\
$\mathbf{4}$ & 8 & 60.00 & 15.00 & 12.07 \\
$\mathbf{6}$ & 9 & 60.00 & 15.00 & 12.23 \\
$\mathbf{1 4}$ & 10 & 50.00 & 20.00 & 11.95 \\
$\mathbf{5}$ & 11 & 60.00 & 15.00 & 12.15 \\
$\mathbf{1 5}$ & 12 & 50.00 & 20.00 & 11.91 \\
$\mathbf{1 0}$ & 13 & 60.00 & 25.00 & 0.80 \\
$\mathbf{7}$ & 14 & 40.00 & 25.00 & 0.79 \\
$\mathbf{1 6}$ & 15 & 50.00 & 20.00 & 11.81 \\
$\mathbf{9}$ & 16 & 40.00 & 25.00 & 0.74 \\
$\mathbf{2}$ & 17 & 40.00 & 15.00 & 11.74 \\
\hline
\end{tabular}

From the result, it clearly showed that the highest nitrogen content could be achieved at the centre point level for both of the involved parameters (run no 1, 5,10,12,15 in Table 
2). The lowest nitrogen contents were obtained at low and high level of digestion time against high volume of $\mathrm{H}_{2} \mathrm{SO}_{4}$ (Run no. 2, 3, 13, 14 and 16 in Table 2). Therefore, this indicated that at high level of $\mathrm{H}_{2} \mathrm{SO}_{4}$, it could destroy the nitrogen content in the earthworm regardless of the digestion time.

From the analysis of variance (ANOVA) in Table 3, the Model F-value obtained is 2918.04 which imply that the model is statistically significant. The p-value $<0.0500$ indicates that the model terms are significant. The p-value for Factor A is 0.1154 which shows that the Factor A is not significant; however the p-values for Factor B and AB are 0.0001 and 0.0274 respectively which indicate that the Factors $\mathrm{B}$ and $\mathrm{AB}$ are significant. Moreover, the value of $\mathrm{F}$-values for volume of $\mathrm{H}_{2} \mathrm{SO}_{4}$ is the highest compared to other parameters. It can be inferred that the volume of $\mathrm{H}_{2} \mathrm{SO}_{4}$ play an important role in the nitrogen determination process.

The curvature F-value of 2637.10 implies that there is significant curvature (as measured by difference between the average of the center points and the average of the factorial points) in the design space. The results from ANOVA was further supported by the $\mathrm{R}^{2}$ value shown in Table 4 . The $\mathrm{R}^{2}$ value of 0.9986 shows that the selected factors which are the digestion time and the volume of $\mathrm{H}_{2} \mathrm{SO}_{4}$ and its corresponding levels are highly correlated to the percentage nitrogen content in earthworm powder using the Kjeldahl method.

Table 3: ANOVA for earthworm protein.

\begin{tabular}{lcccccc}
\hline Source & $\begin{array}{c}\text { Sum of } \\
\text { Squares }\end{array}$ & $\begin{array}{c}\text { Degrees of } \\
\text { freedom }(\mathbf{d f})\end{array}$ & $\begin{array}{c}\text { Mean } \\
\text { Square }\end{array}$ & $\begin{array}{c}\mathbf{F} \\
\text { Value }\end{array}$ & $\begin{array}{c}\text { p-value } \\
\text { Prob }>\mathbf{F}\end{array}$ & \\
\hline Model & 14332.62 & 3 & 4777.54 & 2918.04 & $<0.0001$ & significant \\
A-digestion time & 4.72 & 1 & 4.72 & 2.88 & 0.1154 & Not significant \\
B-sulfuric acid & 14317.59 & 1 & 14317.59 & 8744.95 & $<0.0001$ & Significant \\
volume & 10.31 & 1 & 10.31 & 6.30 & 0.0274 & Significant \\
AB & 4317.56 & 1 & 4317.56 & 2637.10 & $<0.0001$ & Significant \\
Curvature & 19.65 & 12 & 1.64 & -- & -- & -- \\
Pure Error & 18669.83 & 16 & -- & -- & -- & -- \\
Cor Total & & & & &
\end{tabular}

Table 4: Analysis of protein content in earthworm.

\begin{tabular}{lccc}
\hline Std. Dev. & 1.28 & R-Squared & 0.9986 \\
Mean & 50.14 & Adj R-Squared & 0.9983 \\
C.V. \% & 2.55 & Pred R-Squared & 0.9971 \\
PRESS & 41.88 & Adeq Precision & 102.225 \\
\hline
\end{tabular}

Figure 1 shows the graph of half normal plot. Point $\mathrm{AB}, \mathrm{A}$ and $\mathrm{B}$ indicates the positive and negative effect for the factors. Parameters that fall along the straight line are considered as the noise or error from replicates. Factor B is the farthest from the noise with $\mathrm{p}$-value $<0.0001$, while factor $\mathrm{AB}$ with $\mathrm{p}$-value of 0.0274 which is $<0.05$ indicates that these 2 factors are significant. 


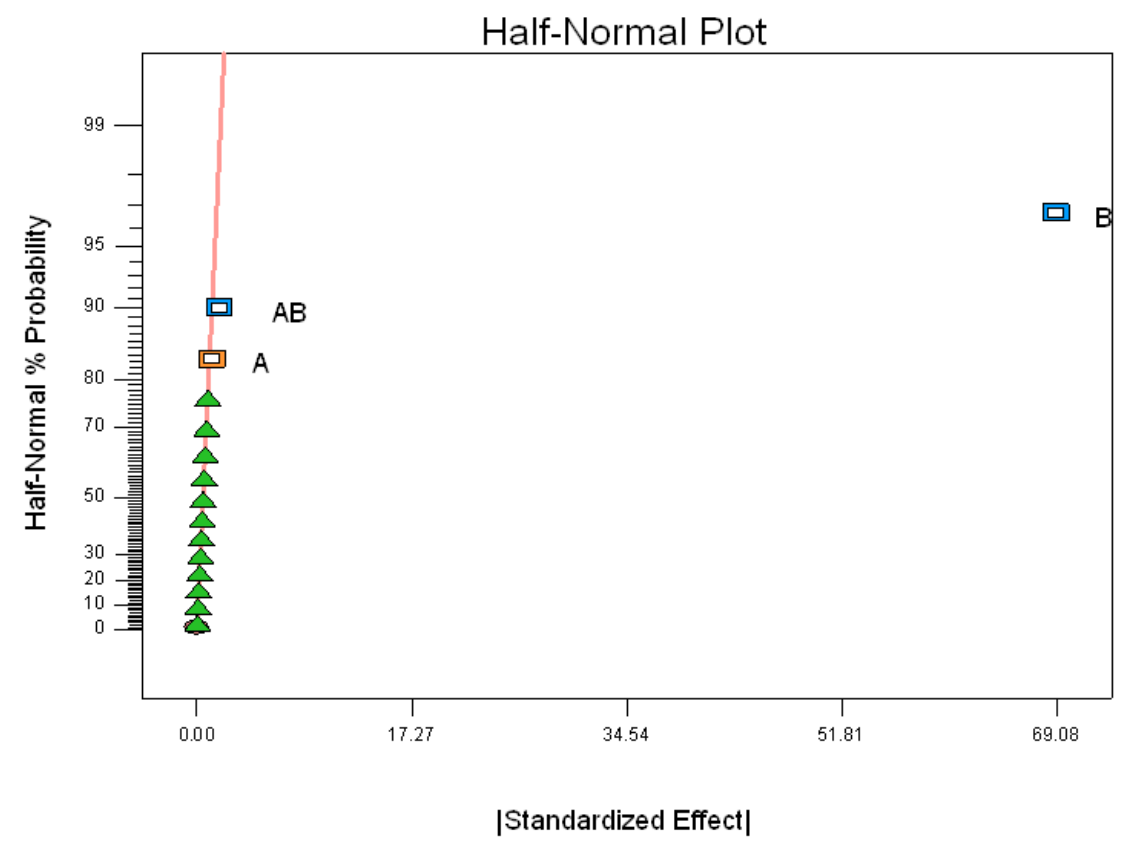

Fig. 1: Graph of half normal plot.

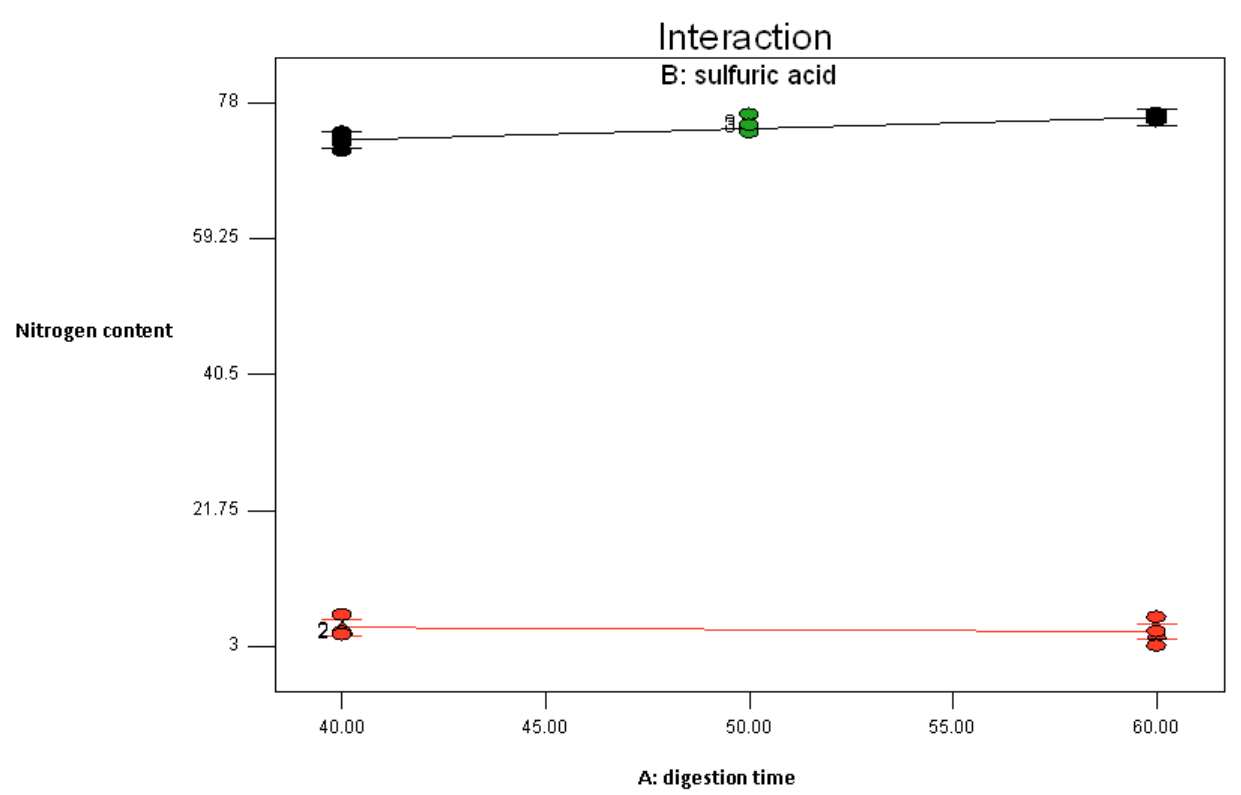

Fig. 2: Graph of slight interaction; $\bullet: 15 \mathrm{ml}$ of $\mathrm{H}_{2} \mathrm{SO}_{4} ; \bullet: 25 \mathrm{ml}$ of $\mathrm{H}_{2} \mathrm{SO}_{4}$.

The interaction graph shows in Fig. 2 is the relationship between the digestion time and the volume of $\mathrm{H}_{2} \mathrm{SO}_{4}$ with its nitrogen yields. It shows the yield of nitrogen content against high level of $\mathrm{H}_{2} \mathrm{SO}_{4}(25 \mathrm{ml})$ and low level of $\mathrm{H}_{2} \mathrm{SO}_{4}(15 \mathrm{ml})$ together with the digestion time (40-60 min). For $15 \mathrm{ml} \mathrm{H}_{2} \mathrm{SO}_{4}$, at $60 \mathrm{~min}$ then nitrogen yield is higher than the other one since a sufficient amount of $\mathrm{H}_{2} \mathrm{SO}_{4}$ was used in digestion. However, the percentage of nitrogen content when using $25 \mathrm{ml} \mathrm{H}_{2} \mathrm{SO}_{4}$ was lower because the excess amount of $\mathrm{H}_{2} \mathrm{SO}_{4}$ results in the loss of nitrogen compound and caused excessive foaming that occurred during the digestion solution. 
Naturally, protein digests by pepsin into amino acid. Besides enzyme, acid can be used to digest protein but in different manner. $\mathrm{H}_{2} \mathrm{SO}_{4}$ originally used by the founder of this method and still being used for its efficacy.

$\mathrm{H}_{2} \mathrm{SO}_{4}$ is an oxidizing agent that reduced nitrogen in food into ammonia and other organic matter. As the organic material is oxidized the carbon content is converted to carbon dioxide and the hydrogen is converted into water. Digestion is the most time consuming step and one of disadvantage of using Kjeldahl method. However, this procedure has enabled the obtainment of nitrogen higher yield at shorter time and this is the advantage of this analysis.

Complete digestion was not achieved by using $\mathrm{H}_{2} \mathrm{SO}_{4}$ alone. The combination of $\mathrm{H}_{2} \mathrm{SO}_{4}$ and high temperature has produced better results. The use of concentrated $\mathrm{H}_{2} \mathrm{SO}_{4}$ at high temperatures poses a considerable hazard.

\section{CONCLUSION}

The nitrogen content in the earthworm powder was statistically analysed using FFD through Kjeldahl method. The statistical tool (FFD) employed in the study has shown that the volume of $\mathrm{H}_{2} \mathrm{SO}_{4}(\mathrm{~B})$ and the interaction between the digestion time and the volume of $\mathrm{H}_{2} \mathrm{SO}_{4}(\mathrm{AB})$ are important parameters in the nitrogen determination process. The highest nitrogen content obtained was $12.23 \%$ when using $15 \mathrm{ml} \mathrm{H}_{2} \mathrm{SO}_{4}$ and 60 mins of digestion time. The conversion of total nitrogen (protein and non-protein) will give a total of $76.465 \%$ crude protein. It was presume only small percentage of non-protein nitrogen existed in earthworm powder $(1.5-2 \%)$ and still the value was higher than previously reported protein content in earthworm, 64.4-72.9\% [18] and 62\% [8].

Therefore, it can be concluded that the determination of nitrogen content using the Kjeldahl method and the statistical software (FFD) enabled the obtainment of the highest crude protein content in earthworm. This indicated that the Kjeldahl method is a robust and fast technique to measure nitrogen content and the application of FFD could enable the appropriate conditions for each parameters involved. Consequently, this could save time, chemicals and raw materials. Since, the protein content of earthworm obtained was high, therefore earthworm proteins could be considered for use as a supplement in animal diets especially for fish cultivation.

Digestion time does not provide much effect to the experiment but yet need to be considered since the longer the digestion time, the temperature will increase. At higher temperature, nitrogen compounds are decomposed to elemental nitrogen, leading to nitrogen loss thus lowering the yield of protein content in earthworm.

\section{ACKNOWLEDGEMENT}

The authors gratefully acknowledge Ministry of Agriculture for the Science Fund (90060006) and School of Bioprocess, University Malaysia Perlis for their financial support and facilities respectively.

\section{REFERENCES}

[1] Musa, Che Utama Che, and Ahmad Adnan Nuruddin. "Trash fish production and national fish feed requirement in Malaysia", Low value and trash fish in the Asia-Pacific region Hanoi, Vietnam. (2007): 107.

[2] S. Rahim and P. Nambiar. "Can't count on bounty of the sea”. New Straits Times, 28 June. 2011.(date retrieved not mention) 
[3] O.A. Sogbesan, A.A.A. Ugwumba, C.T. Madu. "Nutritive potentials and utilization of garden snail (Limicolaria aurora) meat meal in the diet of Clariasgariepinus fingerlings", African Journal of Biotechnology, 5.20 (2003): 1999.

[4] O.A. Fagbenro, K. Jauncey. "Physical and nutritional properties of moist fermented fish silage pellets as a protein supplement for tilapia (Oreochromisniloticus)".. Animal feed science and technology 71.1 (1998): 11-18.

[5] J.R. Sabine. "Earthworms as a source of food and drugs" In Earthwormecology from Darwin to Vermiculture. London: Chapman and Hall, (1986): 285-96.

[6] K.F. Shim, Y.L Chua. "Studies on the protein requirement of the guppy Poeciliareticulate". Journal of Aquariculture and Aquatic Science, 4 (1986): 79-84.

[7] S.S. Basa. "Feed and feedstuffs for aquaculture use in Philippines". Report for the Workshop on Shrimp and Finfish Feed Development. FAO Corporate Document Repository,. (1989): 163.

[8] A.L. Medina, J.A.Cova, R.A. Vielma, P. Pujic, M.P. Carlos, J.V. Torres.'Immunological and Chemical Analysis of Proteins from Eiseniafoetida Earthworm". Food and Agricultural Immunology, 15.3,4,25 (2003): 263.

[9] B. Okutucu, A. Dincer, O.Habib, F. Zihnioglu. "Comparison of five methods for determination of total plasma protein concentration". Journal of .Biochemists and .Biophysics .Methods, 70 (2007): 709-11.

[10] M.V-Martinez, J. L-Hernandez, M.A. L-Yusty. "Protein and amino acid contents in the crab, Chionoecetesopilio". Food Chemistry, 103 (2007): 1330-36.

[11] K. Khodabux, M.S.S.L.' Omelette, S.J-Laulloo, P. Ramasami, P.Rondeau. "Chemical and near-infrared determination of moisture, fat and protein in tuna fishes". Food Chemistry, 102 (2007): 669-75.

[12] Y.Y. Mosleh, S. Paris-Palacios, M.G.V. Couderchet. "Effects of the herbicide isoproturon on survival, growth rate and protein content of mature earthworms (Lumbricusterrestris L.) and its fate in the soil". Applied Soil Ecology,. 23 (2003): 69-77.

[13] S. Metsämuuronen, M. Mänttäri, M. Nyström. "Comparison of analysis methods for protein concentration and its use in UF fractionation of whey".." Desalination 283 (2011): 156-64.

[14] Y.L. Pang, A.Z. Abdullah, S.Bhatia. "Optimization of sonocatalytic degradation of Rhodamine $\mathrm{B}$ in aqueous solution in the presence of $\mathrm{TiO} 2$ nanotubes using response surface methodology". Chemical Engineering Journal,.166 (2011): 873-80.

[15] Montgomery DC, Runger GC: Applied Statistics and Probability for Engineers Fifth Edition, John Wiley and sons, Asia,. (2011): 558.

[16] R Myers, D.C. Montgomery, C.M. Anderson-Cook. "Response Surface Methodology, Process and Product Optimization Using Designed Experiments."', John Wiley and sons, (2011):73

[17] Ministry of Agriculture, Fisheries and Food .Food standards committee report on novel protein foods, FSC/REP/62, HMSO, London. (1975):82.

[18] M.G. Paoletti, E. Buscardo, D.J. Vander Jagt, A. Pastuszyn, L. Pizzoferato, Y-S Huang, L.T Chuang, M. Millson, H. Cerda, F.Torres, R.H Glew. Proc. R. Soc. Lond. B . "Nutrient content of earthworms consumed by Ye'Kuana Amerindians of the Alto Orinoco of Venezuela",270. (2003): 249-57. 


\section{NOMENCLATURE}

$\begin{array}{ll}\mathrm{H}_{2} \mathrm{SO}_{4} & \text { Sulfuric acid } \\ \text { FFD } & \text { Full Factorial Design } \\ \text { UV-Visible } & \text { Ultra-Violet visible } \\ \text { DoE } & \text { Design of Experiment } \\ \text { OFAT } & \text { One-Factor-At-A-Time } \\ \mathrm{NaOH} & \text { Sodium Hydroxide } \\ \mathrm{R} 1 & \text { Response 1 } \\ \text { ANOVA } & \text { Analysis of Variance }\end{array}$

